\section{ANTIHALITOSIS EFFECT OF ESSENTIAL OIL EXTRACTED FROM ZANTHOXYLUM ACANTHOPODIUM FRUITS}

\author{
Yanti*, Berti Priska Gea, Bibiana Widiyati Lay
}

Faculty of Biotechnology, Atma Jaya Catholic University of Indonesia, 12930, Jakarta, Indonesia
Article history

Received

4 March 2019

Received in revised form

4 June 2019

Accepted

17 June 2019

Published online

26 August 2019

*Corresponding author yanti@atmajaya.ac.id

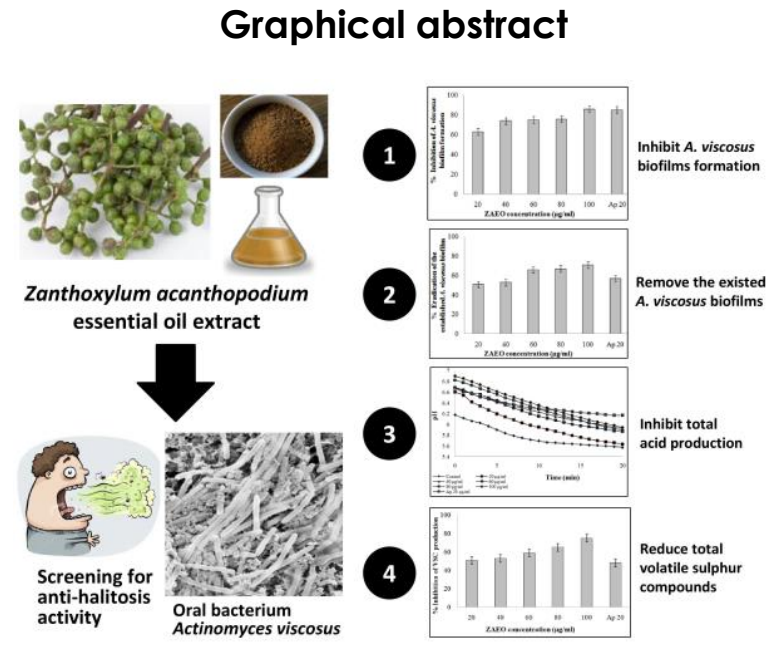

\begin{abstract}
Halitosis is associated with the excessive production of acid and volatile sulphur compounds (VSCs), as well as accumulation of biofilm plaque by oral bacteria in mouth cavity. Zanthoxylum acanthopodium, locally known as andaliman or lemon pepper, is an Indonesian endemic spice with high content of essential oils, including carveol that has been reported for its potential antimicrobial and anti-inflammatory activities. We determined whether extract of $Z$. acanthopodium essential oil (ZAEO) exerted anti-halitosis effect on reducing biofilm plaque, acid production, and VSCs by using Actinomyces viscosus model in vitro. ZAEO was extracted in $n$-hexane followed by evaporation. ZAEO at various doses $(20-100 \mu \mathrm{g} / \mathrm{ml})$ was tested and quantified for its antibiofilm, acid production, and total VSCs production toward $A$. viscosus oral bacteria in vitro by conducting biofilm assays for preventing and eradicating effects, $\mathrm{pH}$-stat analysis, and VSCs assay. At lowest dose $(20 \mu \mathrm{g} / \mathrm{ml})$, ZAEO inhibited and removed $>50 \%$ of $A$. viscosus biofilms. A. viscosus was able to produce acid rapidly in 20 minutes, resulting in the $\mathrm{pH}$ terminal of 5.57 , and ZAEO treatment at $40 \mu \mathrm{g} / \mathrm{ml}$ exerted significant inhibition on acid production with the terminal $\mathrm{pH}$ of 5.93 , respectively. ZAEO at lowest dose also reduced $>50 \%$ of total VCSs produced by A. viscosus. Our results suggest that ZAEO extract could be applied as a natural ingredient for halitosis treatment.
\end{abstract}

Keywords: Actinomyces viscosus, anti-halitosis activity, biofilms, acid production, volatile sulphur compounds, Zanthoxylum acanthopodium essential oil.

(c) 2019 Penerbit UTM Press. All rights reserved

\subsection{INTRODUCTION}

Halitosis (oral malodour) is indicated by bad smell from mouth due to the production of volatile sulphur compounds (VSCs) by oral bacteria. Halitosis is mostly caused by less oral hygene, periodontal infection, food residue, oral carsinoma, and throat infection [1]. Physiologically, halitosis is caused by food component that is consumed and morning breath.
During sleep, the flow of saliva decreased, consequently the oral hygiene can not be kept due to the growth of bacteria. Meanwhile, oral pathology of halitosis is caused by accumulation of dental plaque, periodontal infection, the growth, and biofilm of oral bacteria. Dental plaque is caused by less of oral hygene consequently the bacteria decompose food residue. Periodontal disease is characterized by the swollen gum. Several early and 
late oral bacterial colonizers, including Streptococcus mutans, S. sanguinis, Actinomyces viscosus, Fusobacterium nucleatum, Prevotella intermedia, and Tannerella forsythensisis have reported to be highly significant to produce VSCs [2]. If combine with Porphyromonas gingivalis and $P$. endodontalis, they may cause periodontal disease.

Halitosis occurs in all ages and appears due to the decompositon protein by bacterial and host proteases. Halitosis can be treated by the use of natural substances, such as plant extracts and chemical substances. However, the use of chemical subtances often causes side effects. The chemical substances, like triclosan, cetilpiridinium chloride, chlorhexidine contained alcohol as an antiseptic agent. The use of these agents in may cause tooth staining and decrease saliva flow [1,3]. Alternative strategics for halitosis treatment are focused on the use of natural products derived from plant extracts. Zanthoxylum acanthopodium fruit, locally known as andaliman or lemon pepper, belongs to an endogenous spice grouped in Rutaceae family in Indonesia and has a unique lemon aromatic flavor [4]. Previous studies showed that Z. acanthopodium fruit contained up to $69 \%$ of essential oils, including monoterpenes and diterpenes, and possessed pharmacological effect, such as antibacterial, antioxidant, antidiabetic, anti-inflammatory, and xanthine oxidase inhibitory activities $[5,6,7,8]$. However, the essential oil derived from $Z$. acanthopodium fruit has not been reported for its potency and mechanism to combat halitosis. This study was focused on determining the antihalitosis effect of Z. acanthopodium essential oil (ZAEO) on inhibiting and removing biofilm plaque, reducing acid production and inhibiting production of VSCs using oral bacteria Actinomyces viscosus.

\subsection{METHODOLOGY}

\subsection{Plant Material}

The fruits of Z. acanthopodium were purchased from traditional market in Central Tapanuli region, North Sumatera province (Indonesia). The fruits were identified by Herbarium Bogoriense, Bogor Botanical Garden, Bogor (Indonesia) and stored in a voucher specimen (code: LY25) at Faculty of Biotechnology, Atma Jaya Catholic University of Indonesia. Z. acanthopodium fruits (pericarp and seed) were dried using freeze dryer and grinded to obtain the powder.

\subsection{Extraction of Essential Oil from Z. acanthopodium}

Essential oil from Z. acanthopodium (ZAEO) fruit was extracted using $\mathrm{n}$-hexane. A $40 \mathrm{~g}$ of dried fruit of Zanthoxylum was weighted and soaked in $200 \mathrm{~mL} n$ hexane and agitated $120 \times g$ using shaker incubator at room temperature. After $48 \mathrm{~h}$, the solid particle was sieved by filter paper. Essential oil and the $n$ hexane were separated using rotary evaporator at $50^{\circ} \mathrm{C}$ and 350 mbar. After extraction, n-hexane residue was evaporated and ZAEO was obtained. Our previous results showed the ZAEO contained $69.03 \%$ of essential oils with major compounds of carveol (47.7\%), myrtanyl acetate (12.55\%), phytol (2.81\%), and citronellyl acetate (2.77\%) [9].

\subsection{Antibiofilm Assay}

Antibiofilm activity of ZAEO was assayed for prevention and eradication effects using $A$. viscosus biofilm model according to the modified method of Yanti et al. [10]. A. viscosus (KCCM 12074) was cultured in brain heart infusion (BHI) broth or BHIA (BHI supplemented with $1.5 \%$ of bacteriological agar at $37^{\circ} \mathrm{C}$ for $24 \mathrm{~h}$ aerobically. For preventing effect, a $1 \%$ of artificial saliva was diluted in adherence buffer $(10$ $\mathrm{mM} \mathrm{KPO}_{4}, 50 \mathrm{mM} \mathrm{KCl}, 1 \mathrm{mM} \mathrm{CaCl} 2,0.1 \mathrm{mM} \mathrm{MgCl}_{2}, \mathrm{pH}$ 7.0) and autoclaved at $121^{\circ} \mathrm{C}$ for $15 \mathrm{~min}$. ZAEO was first dissolved in dimethyl sulfoxide (DMSO) 100\%, followed by a serial dilution of ZAEO using sterilized artificial saliva until the final concentrations of 20-100 $\mu \mathrm{g} / \mathrm{mL}$. ZAEO was added into each well of the 96-well plate, incubated and shaken gently at room temperature for $3 \mathrm{~h}$, followed by air-drying overnight. After coating, a single-species inoculum $\left(1 \times 10^{6}\right.$ $\mathrm{CFU} / \mathrm{ml}$ ) was grown using BHIS media (BHI broth supplemented with $3 \%$ sucrose). For treatment, a 20 $\mu \mathrm{l}$ of cell inoculum was added to the wells (final concentration cells $\left.1 \times 10^{5} \mathrm{CFU} / \mathrm{ml}\right)$. The negative control was BHIS and cell suspension without addition of ZAEO. Ampicillin at $20 \mu \mathrm{g} / \mathrm{ml}$ was used as the reference. After incubation at $37^{\circ} \mathrm{C}$ for $10 \mathrm{~h}$, absorbance at $596 \mathrm{~nm}$ was recorded to assess culture growth. The culture supernatants from each well were decanted, then the planktonic cells were removed by washing with $200 \mu$ of $50 \mathrm{mM}$ PBS $(\mathrm{pH}$ 7.2) and air-dried for $1 \mathrm{~h}$. Biofilm was stained using 110 $\mu$ of $0.4 \%(\mathrm{w} / \mathrm{v})$ crystal violet solution for $30 \mathrm{~min}$, then rinsed with $300 \mu$ of sterile distilled water until the control wells appeared colorless. The quantification of biofilm formation was done through the addition of $200 \mu \mathrm{l}$ of $95 \%$ ethanol as destaining solution to each crystal violet stained well, and $100 \mu \mathrm{\mu l}$ destaining solution was immediately transferred to the new well. This assay was repeated in triplicate.

For the eradication of biofilm, each plate of the 96-well plates was conditioned with $200 \mu \mathrm{l}$ of artificial saliva, incubated, and shaken gently at room temperature $3 \mathrm{~h}$. Then, excess artificial saliva was removed and the plate was air-dried overnight. For negative control, $200 \mu \mathrm{l}$ BHIS broth was used without inoculum. For treatment, a $20 \mu \mathrm{l}$ of single species inoculum was added with $180 \mu \mathrm{l}$ BHIS medium. The plate was incubated at $37^{\circ} \mathrm{C}$ for $10 \mathrm{~h}$. Biofilm cells were treated with $50 \mu \mathrm{l}$ of ZAEO at various final concentrations $(20-100 \mu \mathrm{g} / \mathrm{ml})$, followed by incubation for $60 \mathrm{~min}$. Biofilm cells were stained and quantified. Ampicillin at $20 \mu \mathrm{g} / \mathrm{ml}$ was used as the reference. The percentage of ZAEO activity on 
eradicating $A$. viscosus biofilm was defined as the percentage absorbance of the remained established biofilm after treatment in comparison with the untreated control. This assay was repeated in triplicate.

\subsection{Inhibitory Assay of Acid Production}

Inhibitory effect of ZAEO on acid produced by A. viscosus was determined by using $\mathrm{pH}$-stat analysis [11]. A single-species of inoculum was inoculated in $50 \mathrm{ml}$ of $\mathrm{BHI}$ broth and incubated at $37^{\circ} \mathrm{C}$ for $24 \mathrm{~h}$. Bacterial inoculum was centrifuged at $4500 \times \mathrm{g}$ for 5 min. Pellet were taken and washed with $200 \mathrm{mM} \mathrm{KCl}$ and $20 \mathrm{mM} \mathrm{MgCl}_{2}$. Bacteria was resuspended with 5 $\mathrm{mL}$ salt solution. Sucrose and bacteria without ZAEO were used as control. For treatment, ZAEO at various concentrations $(20-100 \mu \mathrm{g} / \mathrm{ml})$ was added to $5 \mathrm{ml}$ sucrose and $1 \mathrm{ml}$ inoculum bacteria. Ampicillin at 20 $\mu \mathrm{g} / \mathrm{ml}$ was used as the reference. The $\mathrm{pH}$-stat was measured for 20 min within one minute interval. This assay was done in triplicate.

\subsection{Inhibitory Assay of Total VSCs Production}

ZAEO was further tested for its anti-halitosis efficacy through inhibiting the production of VSCs by conducting the modified method of Cord-Ruwisch [12]. The test medium buffer composed of minimal medium ( $\mathrm{pH} 7.0)$ containing $0.5 \%$ methionine and $1 \%$ sucrose with $\mathrm{CuSO}_{4}$ reagent were added in sterile tube in order to detect $\mathrm{H}_{2} \mathrm{~S}$ production. The test tubes was tightly sealed with parafilm and incubated at $37^{\circ} \mathrm{C}$ for $72 \mathrm{~h}$ under aerobic conditions. $\mathrm{H}_{2} \mathrm{~S}$ production was determined by quantitative analysis of colloidal white copper sulphide (CUS) precipitates in the test tubes. For the standard curve, $\beta$ mercaptoethanol at various concentrations (20-100 $\mu \mathrm{g} / \mathrm{ml}$ ) was added to the test medium buffer. For the negative control, minimal medium and $\mathrm{CuSO}_{4}$ reagent without inoculum was added to the sterile tube. The test tubes with ZAEO was compared with the test tubes without ZAEO. The test tubes were treated with $100 \mu \mathrm{l}$ of ZAEO at various concentrations $(20-100 \mu \mathrm{g} / \mathrm{ml})$. Ampicillin at $20 \mu \mathrm{g} / \mathrm{ml}$ was used as the reference. This assay was run in triplicate.

\subsection{Statistical Analysis}

Data were expressed by computational analysis (SPSS 12.0), and the significance of the differences was assessed via a student's t-test. A value of $p<0.05$ was taken as statistically significant.

\subsection{RESULTS AND DISCUSSION}

\subsection{Antibiofilm Activity of ZAEO}

Figure 1 demonstrated the antibiofilm activity of ZAEO against $A$. viscosus oral bacteria by preventing
A. viscosus biofilm formation and eradicating the established A. viscosus biofilm. For preventing effect, at lowest dose $(20 \mu \mathrm{g} / \mathrm{ml})$, ZAEO strongly inhibited up to $63 \%$ of $A$. viscosus biofilm formation in vitro (Figure 1a). ZAEO dose dependently prevented the growth of A. viscosus biofilm. ZAEO at lowest dose also exerted similar eradicating effect on removing $\sim 50 \%$ of the established A. viscosus biofilm (Figure 1b). In general, ZAEO exerted potential antibiofilm activity toward preventing effect of biofilm growth than that of eradicating effect of the existed biofilm. Its antibiofilm efficacy was comparable to that of ampicilin reference used in this study.

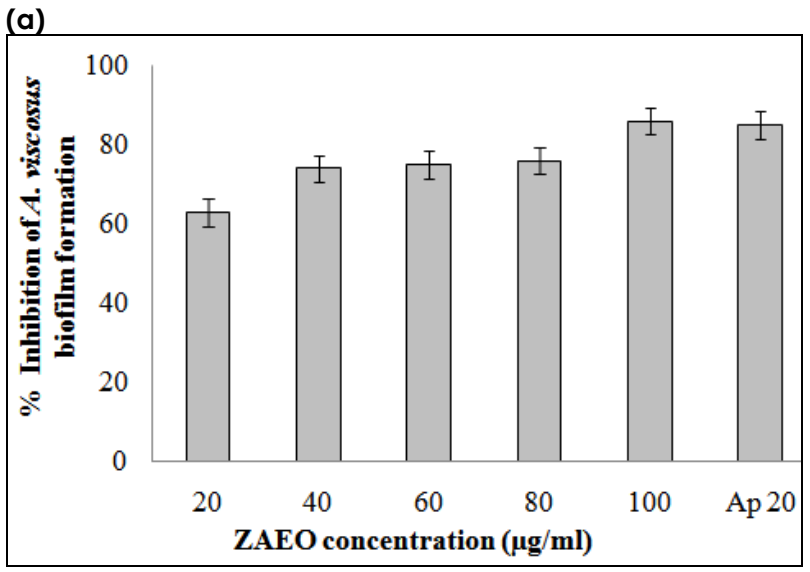

(b)

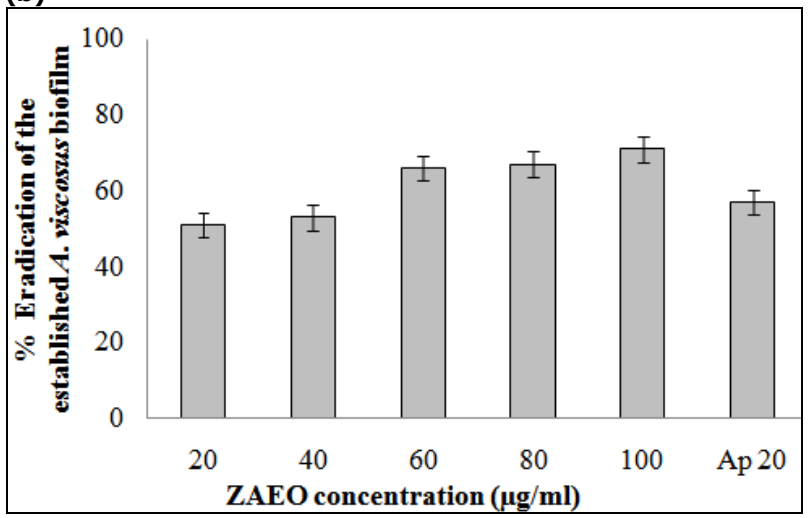

Figure 1 Antibiofilm activity of ZAEO at various concentrations (20-100 $\mu \mathrm{g} / \mathrm{ml}$ ) with preventing effect on $\mathrm{A}$

Halitosis is mainly caused by the accumulation of pathogenic oral bacteria in biofilm plaque that may lead to periodontal infection and inflammation. Halitosis is characterized by the increase of accumulated biofilm plaques, acid production, and VSC production by the bacteria. In this study, we tested whether ZAEO may possess anti-halitosis activity toward $A$. viscosus oral bacteria model by inhibiting biofilm formation, removing the established biofilm, reducing acid production, and decreasing total VSCs production. Our previous study showed that the ethanolic extract of $Z$. acanthopodium fruits possessed anti-inflammatory activity by suppressing 
several inflammatory mediators at protein and gene levels in macrophages induced by lipopolysaccharide [6].

Halitosis is known to be associated with inflammation and infection, thus, active fraction including essential oil extracted from $Z$. acanthopodium fruits using $n$-hexane might be the potential candidate for combating halitosis through several mechanism. Chemical profiling of ZAEO indicated that $69.03 \%$ of essential oil contents in ZAEO and major components were identified as monoterpenes, such as carveol, phytol, myrtanyl acetate, and citronellyl acetate (data not shown). Meanwhile, ZAEO extracted with diethyl eter mostly consisted of geranyl acetate $(32.04 \%)$ and limonene (15.80\%) [5]. The difference of solvent polarity may affect the yield and targeted compounds as the results of extraction. Carveol $(47.70 \%)$ is a monocylic monoterpene alcohol that has been reported for its antimicrobial activity towards Escherichia coli, Salmonella typhimurium, Staphylococcus aureus, Bacillus cereus, and B. subtilis $[8,13]$.

In this study, ZAEO exerted a significant preventive effect toward the growth of A. viscosus biofilms (Figure la). Major components in ZAEO contain hydroxyl active sites of alcohol that may kill cells by increasing the permeability of cytoplasmic membrane and increasing endogenous oxidative stress [14]. ZAEO was found to be easier to remove planktonic cells mode of growth than the existed biofilms. It is noted that planktonic cells cannot maintain to produce the strong toxin and they are easy to detach from the surface. ZAEO was also able to kill the established $A$. viscosus biofilms, although its eradicating effect was not higher than its preventing effect (Figure 1b). Biofilms are built from the matrix cells and lipopolysaccharides, and the matrix is massive and difficult to destroy [15]. It seems that biofilm matrix adsorbs the active components in ZAEO and the bacteria increase their local concentration. ZAEO is extremely difficult to penetrate into the matrix. Planktonic cells are a reversible fashion which is easily killed by ZAEO. If they find the available nutrition or other advantages, they will produce auto-inducer protein (AIP) and start quorum sensing. AlP is a signal in Gram positive to communicate to each other, thus, they increase their density. ZAEO is difficult to interact with bacteria in matrix-enclosed biofilm formations [16]. Biofilms grow and colonize in tooth surface and release occassionally planktonic cells that react with ZAEO. Bacteria living as biofilm are often more difficult to eradicate compared to the planktonic cells.

In terms of ZAEO effect on eradicating the established A. viscosus biofilm, it is assumed that penetration of ZAEO into matrix biofilms is also influenced by their molecular weights (MWs) [17]. Molecules with small size may easily penetrate into the matrix. Carveol as the main essential oil component in ZAEO has lower MW $(152.23 \mathrm{~g} / \mathrm{mol})$ than that of ampicillin reference (MW $349.41 \mathrm{~g} / \mathrm{mol}$ ). Terpenes as the major component of essential oil have a spesific mechanism to inhibit and eradicate biofilms. Other factor might be correlated with characteristic of terpenes in ZAEO. Terpenes influence the fatty acid composition of cell membrane, disrupt the membrane by lipophilic compounds, and thereby inhibit ion transport. Terpenes are also potential to prevent aggregation and biofilm formation [18]. Carveol as a monoterpene has been reported to exert antibacterial activity toward Escherichia coli and Staphylococcus aureus through changing the hydrophobicity, surface charge, and membrane integrity with the subsequent $\mathrm{K}^{+}$leakage [19].

\subsection{Effect of ZAEO on Acid Production}

The ZAEO was further tested on its potency on inhibiting the acid produced by $A$. viscosus in vitro. In Figure 2, A. viscosus was able to produce acid rapidly in $20 \mathrm{~min}$, resulting in terminal $\mathrm{pH}$ of 5.57 and treatment with ZAEO effectively reduced the terminal $\mathrm{pH}$ and the acid production rate. At $40 \mu \mathrm{g} / \mathrm{ml}$, ZAEO effectively increased the terminal $\mathrm{pH}$ to 5.93 and its ability was quite similar to ampicilin reference on inhibiting acid produced $A$. viscosus.

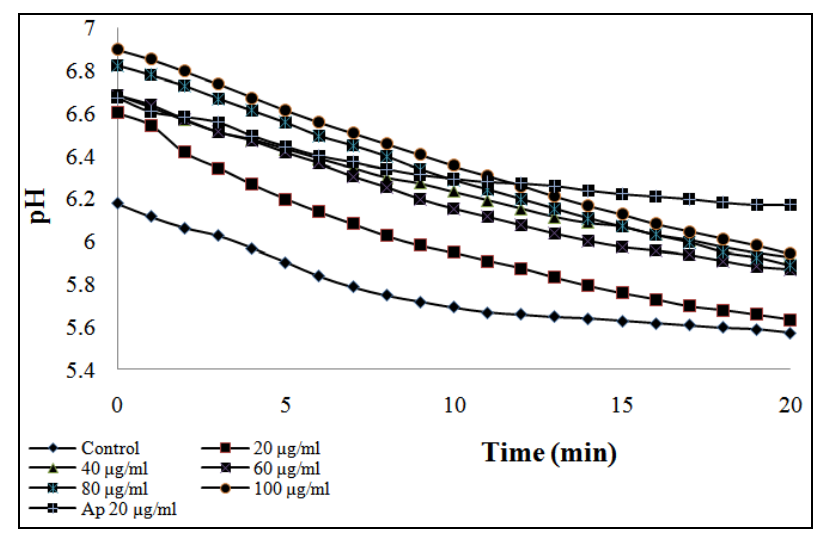

Figure 2 Effect of ZAEO at various concentrations (20-100 $\mu \mathrm{g} / \mathrm{ml}$ ) on inhibiting $\mathrm{A}$. viscosus acid production by $\mathrm{pH}$ stat assay. Ap 20 was ampicillin reference at $20 \mu \mathrm{g} / \mathrm{ml}$. $\mathrm{P}<0.05$ against control (untreated $A$. viscosus)

These data indicate that ZAEO may inhibit glucosyltransferase (GTF) activity that leads to the decrease of glucan formation and acidogenecity [20]. Oral bacteria S. mutans encode gtfB, gtfC, gtfD genes to produce GTF, and GTF converts sucrose to the modified glucans. Next, glucanase converts glucans to glucose, and glucose is converted to acid via heterofermentative metabolisme [21]. It is known that sucrose metabolism is associated with caries and halitosis in management of periodontal diseases. Oral bacteria breakdown the sucrose and other carbon sources to synthesize energy via glycolysis pathway. Acid is a by-product of metabolism that can dissolve calcium phosphate in teeth and cause caries [22]. Acid caused halitosis is produced by Gram positive via tricarboxylic acid (TCA) cycle. 
Sucrose is converted to glucose and fructose by invertase. In glycolysis pathway, glucose and fructose are converted to phosphoenolpyruvate (PEP). Pyruvate kinase converts PEP to pyruvate, then pyruvate enters the TCA generating metionine, cysteine, and serine [23]. The anaerob metabolism of sucrose by Gram positive produces lactic acid and other organic acids [24]. In addition, VSCs are also produced by other bacteria that live together with $A$. viscosus that supply lactic acid to Veillonella species. Hence, Veillonella produces hydrogen sulfide from lactic acid [25]. Inhibition of acid production may cause the decrease of dextran production as the adhesion factor of bacteria to teeth surface. The decrease of $A$. viscosus density may lead to the reducing of protein metabolism.

\subsection{Effect of ZAEO on Total VSCs Production}

ZAEO was also investigated for its ability to decrease total VSCs produced by A. viscosus in vitro. ZAEO inhibited total VSC production in the dose dependent manner (Figure 3). Interestingly, at lowest dose $(20 \mu \mathrm{g} / \mathrm{ml})$, both ZAEO and ampicillin demonstrated the similar effect on inhibiting up to $50 \%$ of VSCs production.

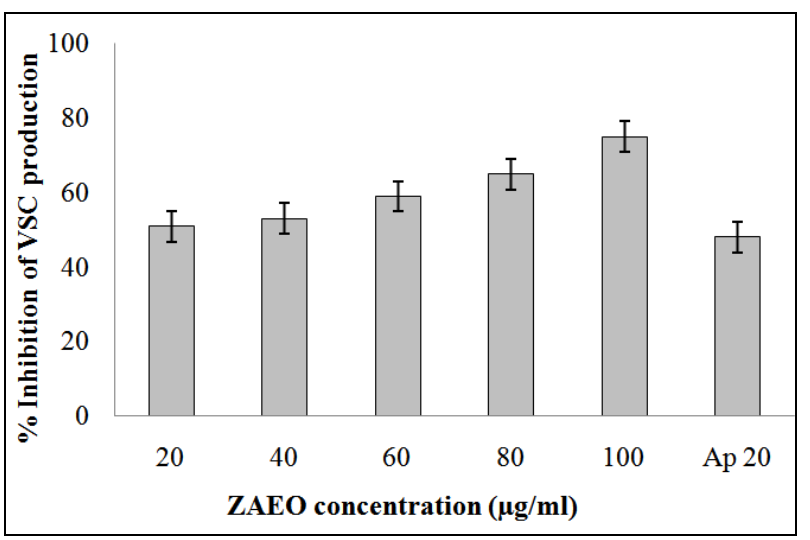

Figure 3 Effect of ZAEO at various concentrations (20-100 $\mu \mathrm{g} / \mathrm{ml}$ ) on inhibiting total VSCs produced by A. viscosus. Ap 20 was ampicillin reference at $20 \mu \mathrm{g} / \mathrm{ml}$. P<0.05 against control (untreated A. viscosus)

It is known that $A$. viscosus produce VSCs from degradation of protein containing sulphur. Cysteine is degraded by $A$. viscosus via desulfhydration mechanism. Degradation of cysteine generates hydrogen sulfide as a VSC product [26]. Washio et al. also reported that $A$. viscosus is a predominant bacteria which produces hydrogen sulfide [25]. We assumed that ZAEO efficacy on inhibiting VSCS production is associated with its potential antibiofilm activity either to prevent $A$. viscosus biofilm formation or to eradicate the existed $A$. viscosus biofilm (Figure 1). Antibiofilm effect of ZAEO toward A. viscosus biofilm may suppress total VSCs produced by A. viscosus itself.

\subsection{CONCLUSION}

In summary, essential oils rich in carveol isolated from the fruits of $Z$. acanthopodium may exert antihalitosis potential through several mechanisms, including preventing the growth of A. viscosus biofilms, eradicating the established $A$. viscosus biofilms, inhibiting acid production, and reducing total VSCS production.

\section{Acknowledgement}

This study was funded by the 2015 Faculty Grant for Graduate Student from Institute for Research and Community Service, Atma Jaya Catholic University of Indonesia, Jakarta (Indonesia).

\section{References}

[1] Aylikci, B. U., Colak, H. 2013. Halitosis: From Diagnosis to Management. The Journal of Natural Science, Biology and Medicine. 4(1): 14-23. DOI: http://dx.doi.org/10.4103/0976-9668.107255.

[2] Patil, S. H., Kulloli, A., Kella, M. 2011. Unmasking Oral Malodor: A Review. People's Journal of Scientific Research. 5(1): 61-67.

[3] Erawati, S., Rahardjo, A., Pintauli, S. 2014. Clinical Effifacy of A New Mouthwash Containing Essential Oil of Cardamon in Reducing Volatile Sulphur Compounds Cencentration. International Journal of Clinical Preventive Dentistry. 10(4): 237-242.

[4] Kristanty, R. E., Suriawati, J. 2015. The Indonesian Zanthoxylum acanthopodium DC: Chemical and Biological Values. International Journal of Pharm Tech Research. 8(6): 313-321.

[5] Wijaya, C. H., Hadiprodjo, I. T., Apriyantono, A. 2002. Identification of Volatile Compounds and Key Aroma Compunds of Andaliman Fruit (Zanthoxylum acanthopodium DC.). Food Science and Biotechnology. $11(6)$ : 680-683.

[6] Yanti, R. Y., Lee, K. H., Hwang, J. K. 2009. Activity of Panduratin a Isolated from Kaempferia pandurata Roxb. against Multi-species Oral Biofilms In Vitro. Journal of Oral Science. 51(1): 87-95.

[7] Negi, J. S., Bisht, V. K., Bhandari, A. K., Bisht, R., Negi, S. K. 2012. Major Constituents, Antioxidant and Antibacterial Activities of Zanthoxylum armatum DC. Essential Oil. International Journal of Pharmacy and Technology. 11 (2): 68-72.

[8] Parhusib, A. J, Jenie. B. S., Rahayu, W. P., Yasni, S. 2005. Effect of Andaliman (Zanthoxylum acanthopodium DC.) Extract upon Permeability and Hydrophobicity of Bacillus cereus. Jurnal Teknologi dan Industri Pangan. 16(1): 24-30. (in Indonesian).

[9] Yanti, Limas RW. 2019. Chemical profiling of Zanthoxylum acanthopodium essential oil and its antidiabetic activity. Food Research. 3(5):422-427.

[10] Yanti, R. Y., Kim, K. H., Hwang, J. K. 2008. In vitro Antibiofilm Activity of Macelignan Isolated from Myristica fragrans Houtt. against Oral Primary Colonizer Bacteria. Phytotherapy Research. 22(3): 308-312.

[11] Percival, R. S., Devine, D. A., Duggal, M. S., Chartron, S., Marsh, P. D. 2006. The Effect of Cocoa Polyphenols on the Growth, Metabolism, and Biofilm Formation by Streptococcus mutans and Streptococcus sanguinis. European Journal of Oral Sciences. 114(1): 343-348. DOI: http://dx.doi.org/10.1111/j.1600-0722.2006.00386.x. 
[12] Cord-Ruwish R. 1985. A Quick Method for the Determination of Dissolved and Precipitated Sulfides in Cultures of Sulfate-reducing Bacteria. Journal of Microbiological Methods. 4(1): 33-36. DOI: http://dx.doi.org/10.1016/0167-7012(85)90005-3.

[13] Wang, Y. W., Zeng, W. C., Xu, P. Y., Lan, Y. J., Zhu, R. X., Zhong, K., et al. 2012. Chemical Composition and Antimicrobial Activity of the Essential Oil of Kumquat (Fortunella crassifolia Swingle) Peel. International Journal of Molecular Sciences. 13(3): 3382-3393. DOI: http://dx.doi.org/10.3390/ijms13033382.

[14] Hyldgaard, M., Mygind, T., Meyer, R. L. 2012. Essential Oils in Food Preservation: Mode of Action, Synergies, and Interactions with Food Matrix Components. Frontiers in Microbioloby. 3(12): 1-24. DOI: http://dx.doi.org/10.3389/fmicb.2012.00012.

[15] Kavanaugh, N. L., Ribbeck, K. 2012. Selected Antimicrobial Essential Oil Eradicate Psedomonas sp. and Staphylococcus aureus Biofilms. Applied and Environmental Microbiology. 78(11): 4057-4061.

[16] Stoodley, P., Sauer, K., Davies, D. G., Costerton, J. W. 2002. Biofilms as Complex Differentiated Communities. Annua Review of Microbiology. 56: 187-209. DOI: http://dx.doi.org/10.1146/annurev.micro.56.012302.160705

[17] Watt, M. 2006. Essential Oils: Their Lack of Skin Absorption but Effectiveness via Inhalation. Aromatic Thymes. 3(2): 11 13.

[18] De-Carvalho, C., De-Fonseca, M. 2007. Preventing Biofilm Formation: Promoting Cell Separation with Terpenes. FEMS Microbiology Ecology. 61 (3): 406-413.

[19] Romero, J. C., Rios, H. G., Borges, A., Simoes, M. 2015 Antibacterial Effects and Mode of Action of Selected
Essential Oils Components against Escherichia coli and Staphylococcus aureus. Evidence-Based Complementary and Alternative Medicine. 1: 1-9.

[20] Rahim, Z., Khan, H. 2006. Comparative Studies on the Effect of Crude Aqueous (CA) and Solvent (CM) Extracts of Clove on the Cariogenic Properties of Streptococcus mutans. Journal of Oral Science. 38(3): 117-123. DOI: http://dx.doi.org/10.2334/josnusd.48.117.

[21] Colby, S. M., Russell, R. 1997. Sugar Metabolism by Mutans Streptococci. Journal of Applied Microbiology. 83: 80S88S. DOI: http://dx.doi.org/10.1046/j.1365-2672.83.s1.9.x

[22] Palombo, E. A. 2011. Traditional Medicinal Plant Extracts and Natural Products with Activity against Oral Bacteria: Potential Application in the Prevention and Treatment of Oral Diseases. Evidence-Based Complementary and Alternative Medicine. 1: 1-15. DOl: http://dx.doi.org/10.1093/ecam/nep067.

[23] Kelly, D. J., Hughes, N. J. 2001. The Citric Acid Cycle and Fatty Acid Biosynhesis. In: Mobley, H. L. T., Mendz, G. L. Hazell, S. L., Eds. Helicobacter pylori: Physiology and Genetics. Washington: ASM.

[24] Washio, J., Sato, T., Koseki, T., Takahashi, N. 2005. Hydrogen Sulfide-producing Bacteria in Tongue Biofilm and Their Relationship with Oral Malodour. Journal of Medical Microbiology. 54(Pt 9): 889-895. DOI: http://dx.doi.org/10.1099/jmm.0.46118-0.

[25] Distler, W., Kroncke, A. 1981. Acid Formation by Mixed Cultures of Dental Plaque Bacteria Actinomyces and Veillonela. Archives of Oral Biology. 26: 123-126.

[26] Shibuya, K. 2001. Constituents and Origins of Physiological Malodor. Journal of Dental Health. 51: 778-792. 